\title{
Differences Among International Pharyngitis Guidelines: Not Just Academic
}

Jan Mattbys, MD

Marc De Meyere, MD, PhD

Mieke L. van Driel, MD, MSc

An De Sutter, MD, PbD

Department of Family Medicine and Primary Health Care, Ghent University, Belgium
Conflicts of interest: none reported

\section{CORRESPONDENDING AUTHOR}

Jan Matthys, MD

Department of Family Medicine and Primary Health Care

Ghent University

De Pintelaan 185, UZ-1K3

B-9000 Ghent, Belgium

jan.matthys@ugent.be

\begin{abstract}
PURPOSE Many countries have national guidelines for the treatment of pharyngitis. We wanted to compare the recommendations and the reported evidence in national guidelines for the management of acute sore throat in adults.
\end{abstract}

METHODS Guidelines were retrieved via MEDLINE and EMBASE and through a Web-based search for guideline development organizations. The content of the recommendations and the underlying evidence were analyzed with qualitative and bibliometric methods.

RESULTS We included 4 North American and 6 European guidelines. Recommendations differ with regard to the use of a rapid antigen test and throat culture and with the indication for antibiotics. The North American, French, and Finnish guidelines consider diagnosis of group A streptococcus essential, and prevention of acute rheumatic fever remains an important reason to prescribe antibiotics. In 4 of the 6 European guidelines, acute sore throat is considered a self-limiting disease and antibiotics are not recommended. The evidence used to underpin these guidelines was different in North America and Europe. North American guidelines cited more North American references than did European guidelines (87.2\% vs $48.0 \%$; ods ratio, 4.6-11.9; $P<.001)$.

CONCLUSION Although the evidence for the management of acute sore throat is easily available, national guidelines are different with regard to the choice of evidence and the interpretation for clinical practice. Also a transparent and standardized guideline development method is lacking. These findings are important in the context of appropriate antibiotic use, the problem of growing antimicrobial resistance, and costs for the community.

Ann Fam Med 2007;5:436-443. DOI: 10.1370/afm.741.

\section{INTRODUCTION}

I n many countries, clinical practice guidelines are developed to bridge the gap between research and practice. ${ }^{1}$ In an era of easy access to international research data, we would expect guideline recommendations on the same clinical topic to be similar. ${ }^{2-4}$ Several authors, however, have pointed to differences that could be explained by insufficient evidence, different interpretations of the evidence, unsystematic guideline development methods, the influence of professional bodies, patient preferences, cultural and socioeconomic factors, or characteristics of health care systems. ${ }^{5-18}$ Three studies explored differences of content in relation to differences of the cited scientific evidence supporting the recommendations. ${ }^{7.9}$ Selective use of evidence can lead to differences in practice recommendations and, consequently, to important disparities in patient care and outcome. The World Health Organization (WHO) and other organizations recommend using a rigorous procedure to ensure that practice guidelines are supported by the best available evidence. ${ }^{19-40}$ Nineteen key components of guidelines for guidelines are proposed to improve the use of research evidence.

In this study we focus on guidelines for managing acute sore throat, a relatively straightforward condition for which agreement can be antici- 
pated. The treatment recommendations have public health implications through the use of antibiotics and antibiotic resistance rates. We explore the content of these guidelines and investigate whether potential differences can be explained by variation in the use of scientific evidence. We also evaluate whether the guidelines are in agreement with the $\mathrm{WHO}$ recommendations. ${ }^{10-34}$

\section{METHODS}

We performed a Web-based search for organizations that develop guidelines ${ }^{41}$ on acute sore throat, including the TRIP database, the Cochrane Library, Sumsearch, DARE, Clinical Evidence, EMBASE and MEDLINE (from 1970 to May 2006). We used the MeSH terms "pharyngitis," "sore throat," and "practice guidelines." Systematic reviews and evidence reports without specific practice recommendations were excluded.

The quality of the development method of pharyngitis guidelines was assessed by means of the $19 \mathrm{WHO}$ key components

The recommendations concerning the use of diagnostic tests, treatment (indications for antibiotics, dose, and duration), and criteria for referral were extracted and independently analyzed by 2 authors (M.D.M., J.M.) who have experience in the domain of acute sore throat research. ${ }^{42,43}$ Discrepancies were resolved through discussion.

We compared the cited references for the recommendations in each guideline. The number of references and the overlap of citations was quantified by calculating the proportion of shared references among guidelines according to the publication dates of the guideline and its references. ${ }^{7}$ For each reference we determined the study design (meta-analysis, review, randomized controlled trial, other) and the country of origin (North America, Europe, other). Citations (expressed as proportions) were compared using Fisher's exact test. For statistical analysis we used SPSS 12.0 (SPSS Inc, Chicago, Illinois).

\section{RESULTS}

\section{Selection of Guidelines}

We identified 14 guidelines and included 10 in our analysis: 6 from Western Europe, 3 from the United States, and 1 from Canada (Table 1$).{ }^{44-53}$ Four guide-

Table 1. Characteristics of Selected Guidelines on Acute Sore Throat

\begin{tabular}{|c|c|c|c|c|c|}
\hline $\begin{array}{l}\text { Country } \\
\text { (+ code) }\end{array}$ & $\begin{array}{l}\text { Organization } \\
\text { Responsible } \\
\text { for Guideline } \\
\text { Development }\end{array}$ & $\begin{array}{l}\text { Web Sites of the } \\
\text { Selected Guidelines }\end{array}$ & Title in English & $\begin{array}{l}\text { Year of } \\
\text { Publication } \\
\text { (No. of } \\
\text { Pages) }\end{array}$ & $\begin{array}{c}\text { Levels of } \\
\text { Evidence or } \\
\text { Grades of } \\
\text { Recommendation }\end{array}$ \\
\hline $\begin{array}{l}\text { Belgium } \\
\left(_{(B E 01)^{44}}\right.\end{array}$ & $\begin{array}{l}\text { Scientific Organisation of } \\
\text { Flemish GPS, WVVH }\end{array}$ & $\begin{array}{l}\text { http://www.health.fgov. } \\
\text { be/antibiotics/ }\end{array}$ & $\begin{array}{l}\text { Acute Sore Throat: Guide- } \\
\text { lines for Good Clinical } \\
\text { Practice }\end{array}$ & 1999 (11) & No \\
\hline $\begin{array}{l}\text { The Netherlands } \\
(\mathrm{NLO} 2)^{45}\end{array}$ & $\begin{array}{l}\text { Dutch College of General } \\
\text { Practitioners, NHG }\end{array}$ & http://nhg.artsennet.nl & $\begin{array}{l}\text { Standard Acute Sore } \\
\text { Throat }\end{array}$ & $1999(8)$ & No \\
\hline $\begin{array}{l}\text { France } \\
\qquad(\text { FRO3) }\end{array}$ & Agence du Médicament & $\begin{array}{l}\text { http://agmed.sante. } \\
\text { gouv.fr }\end{array}$ & $\begin{array}{l}\text { Antibiotic Therapy by } \\
\text { General Way in General } \\
\text { Practice: ENT Infections }\end{array}$ & $1999(8)$ & Yes \\
\hline $\begin{array}{l}\text { Finland } 47 \\
\qquad(\mathrm{FlO4})\end{array}$ & Duodecim & http://www.guideline.gov & Sore Throat and Tonsillitis & $2001(4)$ & Yes \\
\hline $\begin{array}{l}\text { England } 48 \\
\text { (E05) }\end{array}$ & $\begin{array}{l}\text { National Health Service, } \\
\text { PRODIGY }\end{array}$ & www.prodigy.nhs.uk & Acute Sore Throat & $2004(9)$ & Yes \\
\hline $\begin{array}{l}\text { Scotland }{ }^{49} \\
\text { (SCO6) }\end{array}$ & $\begin{array}{l}\text { Scottish Intercollegiate } \\
\text { Guidelines Network } \\
\text { (SIGN) }\end{array}$ & www.sign.ac.uk & $\begin{array}{l}\text { Management of Sore } \\
\text { Throat and Indications } \\
\text { for Tonsillectomy }\end{array}$ & $1999(24)$ & Yes \\
\hline $\begin{array}{r}\text { Canada } \\
\text { (CA07) }\end{array}$ & $\begin{array}{l}\text { Canadian Medical Asso- } \\
\text { ciation (CMA) }\end{array}$ & http://www.hlth.gov.bc.ca & $\begin{array}{c}\text { Diagnosis and Manage- } \\
\text { ment of Sore Throat }\end{array}$ & $2001(4)$ & No \\
\hline $\begin{array}{l}\text { United States }{ }^{51} \\
\text { (US08) }\end{array}$ & $\begin{array}{l}\text { Institute for Clinical } \\
\text { Systems Improvement } \\
\text { (ICSI) }\end{array}$ & www.guideline.gov & Acute Pharyngitis & $2005(33)$ & Yes \\
\hline $\begin{array}{l}\text { United States } \\
\text { (US09) }\end{array}$ & $\begin{array}{l}\text { Infectious Disease Soci- } \\
\text { ety of America (IDSA) }\end{array}$ & www.guideline.gov & $\begin{array}{l}\text { Practice Guidelines } \\
\text { for the Diagnosis } \\
\text { and Management of } \\
\text { Group A Streptococcal } \\
\text { Pharyngitis }\end{array}$ & $2002(13)$ & Yes \\
\hline $\begin{array}{l}\text { United States } \\
\text { (US10) }\end{array}$ & $\begin{array}{l}\text { American College of } \\
\text { Physicians \& American } \\
\text { Society of Internal } \\
\text { Medicine-Centers for } \\
\text { Disease Control and } \\
\text { Prevention (ACPIASIM) }\end{array}$ & www.guideline.gov & $\begin{array}{l}\text { Principles of Appropriate } \\
\text { Antibiotic Use for Acute } \\
\text { Pharyngitis in Adults } \\
\text { (+ Background) }\end{array}$ & 2001 (12) & Yes \\
\hline
\end{tabular}


lines aimed at children only were excluded (United Kingdom, Finland, Michigan, Singapore). All the European guidelines-Belgium (BE01), the Netherlands (NL02), France (FR03), Finland (FI04), England (E05), and Scotland (SC06) 44-49 — were national guidelines. The Canadian guideline (CA07) was disseminated by the Government of British Columbia. ${ }^{50}$ The US guidelines (US08, US09, US10) were identified through the National Guideline Clearinghouse. ${ }^{51-53}$

\section{Comparison of Recommendations}

\section{Points of Agreement}

The guidelines are in agreement on the general management of patients with acute sore throat in the following recommendations (Table 2). Group A $\beta$-hemolytic streptococcus (GABHS) is accepted as a pathogen for the diagnosis. No internationally accepted clinical scoring system (based on history and physical examination) can sufficiently predict a positive throat culture and guide antibiotic treatment without further investigation. Serologic tests (antistreptolysin O, C-reactive protein, leukocyte count) are not recommended. For the treatment of acute sore throat, narrow-spectrum penicillin is the first choice of antibiotic for the treatment of GABHS. Nearly all agree that antibiotics aim to shorten the clinical evolution, relieve symptoms, and limit the spread of GABHS in the case of high-risk and very ill patients. Antibiotics are not indicated for the prevention of acute glomerulonephritis.

\section{Differences Among Guidelines}

For the diagnosis of GABHS, the Centor criteria ${ }^{54}$ (fever greater than $38.5^{\circ} \mathrm{C}$, absence of cough, tonsillar exudate, and enlarged cervical glands) are used in only 4 guide-

lines (US08-10, CA07). In the clinical decision model of US10, the rapid antigen test is recommended when 2 or 3 Centor criteria are present. There is no international consensus on the use of the rapid antigen test: it is recommended in the 3 US guidelines and in the French and Finnish guidelines. The others do not recommend its use because of the high prevalence of streptococcal carriers (5\% to $20 \%)$ and its modest sensitivity $(65 \%$ to $80 \%)$ in primary health care (BE01, NL02, SC06). Recommendations on the use of a throat culture also differ. A throat culture is advised in 2 US (US08, US09), the Canadian, and Finnish guidelines. One US guideline recommends a throat culture when the rapid antigen test result is negative for GABHS or when the test is not available (US08). According to the Belgian, Dutch, French, Scottish, English, and 1 North American guideline (US10), the results of a throat culture arrive too late to have a major influence on the clinical course, and a throat culture is therefore not recommended.

For treatment, there is no consensus on the use of antibiotics. Prevention of acute rheumatic fever is a major reason to recommend antibiotics in the North American (CA07, US08, US09, US10), French, and Finnish guidelines. Prevention of local complications (retrotonsillar abscess, sinusitis, otitis media) is another reason to prescribe antibiotics in 2 US (US09 and US10) and the Canadian (CA07) guidelines. In the North American, French, and Finnish guidelines, antibiotics are advised when a rapid antigen test result or throat culture is positive for GABHS. All guidelines recommend penicillin as first choice; however, French guidelines recommend aminopenicillins and cephalosporins.

\section{Quality of Assessed Guidelines}

It was not possible to score the guideline development method according to the 19 WHO key components, because they were seldom explicitly mentioned in the clinical guidelines (priority setting, group composition and consultations; declaration and avoidance of conflicts of interest ${ }_{i}$ group processes; identification of important outcomes; explicit definition of the questions and eligibility criteria; type of study designs for different questions; identification of evidence; synthesis and presentation of evidence; specification and integration of values; making judgments about desirable and undesirable effects; taking account of equity; grading evidence and recommendations; taking account of costs; adaptation, applicability, and transferability of guidelines; structure of reports; methods of peer review; planned methods of dissemination and implementation; and evaluation of the guidelines). It was also impossible to infer these components. We therefore evaluated only 1 key component, ie, identification of evidence.

\section{Comparison of Evidence}

The 10 guidelines included a total of 544 references of which 308 were different. Fifty-eight references were shared by 2 guidelines. Eight guidelines used the same 2 references to studies on rheumatic fever that were published in the $1950 \mathrm{~s} .{ }^{55,56}$ Not one of the available meta-analyses (eg, Cochrane review) or landmark studies was used in all the guidelines. Most first authors of the studies cited in the guidelines $(63.8 \%)$ originated from North America. North American guidelines cited more North American publications than did European guidelines $(87.2 \%$ vs $48.0 \%$; odds ratio, 4.6-11.9; $\mathrm{P}<.001$ ) (Table 3). In 2 North American guidelines (US08, US09) only $2 \%$ of the references referred to non-American studies; no mention was made of the 3 European randomized placebo controlled clinical trials published in the $1990 \mathrm{~s}^{42,57,58}$ or the Cochrane review. Only 1 US guideline (US10) referred to 21 European references (of a total of 72 references), including the 3 European trials. ${ }^{42,57,58}$ 


\begin{tabular}{|c|c|c|c|c|c|c|c|c|c|c|}
\hline \multirow[b]{2}{*}{$\begin{array}{l}\text { Diagnosis and } \\
\text { Treatment }\end{array}$} & \multicolumn{6}{|c|}{ European Guidelines } & \multicolumn{4}{|c|}{ North American Guidelines } \\
\hline & $\begin{array}{c}\text { Belgium }^{44} \\
\text { BE01 }\end{array}$ & $\begin{array}{l}\text { The } \\
\text { Netherlands }{ }^{45} \\
\text { NL02 }\end{array}$ & $\begin{array}{l}\text { France } 46 \\
\text { FR03 }\end{array}$ & $\begin{array}{l}\text { Finland }^{47} \\
\text { FI04 }\end{array}$ & $\begin{array}{l}\text { England } 48 \\
\text { E05 }\end{array}$ & $\begin{array}{l}\text { Scotland }{ }^{49} \\
\text { SC06 }\end{array}$ & $\begin{array}{l}\text { Canada }^{50} \\
\text { CA07 }\end{array}$ & $\begin{array}{l}\text { ICSI }^{51} \\
\text { us08 }\end{array}$ & $\begin{array}{l}\text { IDSA } 52 \\
\text { US09 }\end{array}$ & $\begin{array}{c}\text { Position } \\
\text { Paper } \\
\text { (ACP) })^{33} \\
\text { US10 }\end{array}$ \\
\hline \multicolumn{11}{|l|}{ Diagnosis } \\
\hline History & + & + & + & + & + & + & + & + & + & + \\
\hline Clinical examination & + & + & + & + & + & + & + & + & + & + \\
\hline Centor criteria & - & - & - & - & - & - & + & + & + & + \\
\hline $\begin{array}{l}\text { GABHS (rapid antigen } \\
\text { or strep) test }\end{array}$ & - & - & + & + & - & - & - & + & + & + \\
\hline Culture & - & - & - & + & - & - & + & $+^{*}$ & $+^{*}$ & - \\
\hline \multicolumn{11}{|l|}{ Treatment } \\
\hline \multicolumn{11}{|l|}{ Prescribe antibiotics } \\
\hline $\begin{array}{l}\text { High-risk and very } \\
\text { ill patients }\end{array}$ & + & + & + & - & + & + & + & + & + & + \\
\hline Centor criteria & - & - & - & - & - & - & - & - & - & + \\
\hline $\begin{array}{l}\text { GABHS test result } \\
\text { positive }\end{array}$ & - & - & + & + & - & - & - & + & + & + \\
\hline $\begin{array}{l}\text { GABHS test result } \\
\text { negative; culture } \\
\text { positive }\end{array}$ & - & - & + & + & - & - & - & + & + & - \\
\hline Culture positive & - & - & - & + & - & - & + & + & + & - \\
\hline \multicolumn{11}{|l|}{ Reason for antibiotics } \\
\hline $\begin{array}{l}\text { Shorten clinical } \\
\text { evolution }\end{array}$ & + & + & + & + & - & - & + & + & + & + \\
\hline Prevent ARF & - & - & + & + & - & - & + & + & + & + \\
\hline Prevent GNF & - & - & - & - & - & - & - & - & - & - \\
\hline $\begin{array}{l}\text { Prevent local } \\
\text { complications }\end{array}$ & - & - & - & - & - & - & + & - & + & + \\
\hline $\begin{array}{l}\text { Limit spread of } \\
\text { GABHS }\end{array}$ & - & + & + & + & + & + & + & + & + & + \\
\hline $\begin{array}{l}\text { Small-spectrum } \\
\text { penicillin }\end{array}$ & + & + & + & + & + & + & + & + & + & + \\
\hline
\end{tabular}

\section{DISCUSSION}

We have identified fundamental differences in the recommendations for the management of acute sore throat, in particular among guidelines from North America, France, and Finland on the one hand, and from Belgium, The Netherlands, England, and Scotland on the other. Recommendations differ with regard to the use of a rapid antigen test or throat culture and the indication for antibiotics. North American, French, and Finnish guidelines consider diagnosis of GABHS necessary, and prevention of acute rheumatic fever remains an important reason to recommend antibiotics. In 4 of the 6 European guidelines, acute sore throat is considered a self-limiting disease, and antibiotics are not recommended. The evidence used to underpin the guidelines was different in North America and Europe. Our bibliographic analysis shows that North American guidelines mainly rely on publications from authors of the same region.

To our knowledge, this study is the first that simul- taneously compares the clinical content of the recommendations and the evidence of guidelines on acute sore throat. Although many national sore throat guidelines are easily available on the Internet, not all existing guidelines could be identified through the indexed literature or the Internet. Consequently, a potential limitation of our study is that we included only a selection of all national guidelines and omitted regional or local guidelines. Also, the effect of guidelines on public health in specific regions still needs to be studied. Even a well-constructed guideline is a hypothesis that needs to be tested unless it has been based on the results of practice-based effectiveness trials.

\section{Explaining Differences in Recommendations}

The North American, French, and Finnish guidelines recommend prescribing antibiotics to prevent acute rheumatic fever if streptococcal pharyngitis is suspected. This recommendation is most likely based on 


\begin{tabular}{|c|c|c|c|c|c|c|c|c|c|c|c|}
\hline $\begin{array}{l}\text { Type } \\
\text { of Study }\end{array}$ & BE01 & NLO2 & FR03 & FI04 & E05 & SC06 & CA07 & US08 & USO9 & US10 & Total \\
\hline Cochrane, No. & 1 & 1 & 0 & 3 & 2 & 0 & 1 & 0 & 0 & 1 & 9 \\
\hline $\begin{array}{l}\text { Other systematic } \\
\text { reviews, No. }\end{array}$ & 9 & 6 & 4 & 1 & 4 & 5 & 0 & 4 & 0 & 1 & 34 \\
\hline $\begin{array}{l}\text { Randomized con- } \\
\text { trolled trial, No. }\end{array}$ & 23 & 20 & 26 & 1 & 0 & 22 & 1 & 7 & 26 & 17 & 143 \\
\hline Guidelines, No. & 1 & 4 & 4 & 0 & 5 & 2 & 1 & 2 & 7 & 3 & 29 \\
\hline Overview/others & 43 & 54 & 35 & 0 & 5 & 44 & 9 & 26 & 63 & 50 & 329 \\
\hline Total cited, No. & 77 & 85 & 69 & 5 & 16 & 73 & 12 & 39 & 96 & 72 & 544 \\
\hline European, No. (\%) & $\begin{array}{l}35 \\
(45.5)\end{array}$ & $\begin{array}{l}46 \\
(53.5)\end{array}$ & $\begin{array}{l}27 \\
(39.1)\end{array}$ & $\begin{array}{c}1 \\
(20.0)\end{array}$ & $\begin{array}{c}13 \\
(81.3)\end{array}$ & $\begin{array}{c}31 \\
(42.5)\end{array}$ & 0 & $\begin{array}{l}1 \\
(2.6)\end{array}$ & $\begin{array}{l}3 \\
(3.1)\end{array}$ & $\begin{array}{l}21 \\
(29.2)\end{array}$ & $\begin{array}{l}178 \\
(32.7)\end{array}$ \\
\hline American, No. (\%) & $\begin{array}{l}40 \\
(52.0)\end{array}$ & $\begin{array}{l}36 \\
(41.9)\end{array}$ & $\begin{array}{c}39 \\
(56.5)\end{array}$ & $\begin{array}{c}1 \\
(20.0)\end{array}$ & $\begin{array}{c}2 \\
(12.5)\end{array}$ & $\begin{array}{l}38 \\
(52.1)\end{array}$ & $\begin{array}{l}11 \\
(91.7)\end{array}$ & $\begin{array}{l}38 \\
(97.4)\end{array}$ & $\begin{array}{c}92 \\
(95.8)\end{array}$ & $\begin{array}{l}50 \\
(69.4)\end{array}$ & $\begin{array}{l}347 \\
(63.8)\end{array}$ \\
\hline Other, No. (\%) & $\begin{array}{l}2 \\
(2.5)\end{array}$ & $\begin{array}{l}3 \\
(4.6)\end{array}$ & $\begin{array}{l}3 \\
(4.4)\end{array}$ & $\begin{array}{c}3 \\
(60.0)\end{array}$ & $\begin{array}{l}1 \\
(6.2)\end{array}$ & $\begin{array}{l}4 \\
(5.4)\end{array}$ & $\begin{array}{l}1 \\
(8.3)\end{array}$ & 0 & $\begin{array}{l}1 \\
(1.1)\end{array}$ & $\begin{array}{l}1 \\
(1.4)\end{array}$ & $\begin{array}{l}19 \\
(3.5)\end{array}$ \\
\hline
\end{tabular}

the findings of the Fort Warren studies in the United States in the 1950 s. ${ }^{55,56,59-62}$ They found a $0.3 \%$ to $3 \%$ reduction of the incidence of acute rheumatic fever if streptococcal angina was treated with parenteral penicillin. These findings, however, have never been confirmed in other trials with penicillin, ${ }^{63-65}$ nor have they be confirmed in consecutive prospective studies. ${ }^{66-69}$ Almost a half-century ago, an editorial claimed:

The statement that $3 \%$ of such streptococcal infections will be followed by ARF [acute rheumatic fever] rests mainly on the extensive work at Fort Warren, and it is not at all certain that conditions reflect these in general practice. There can therefore be no hard and fast rule that $3 \%$ of streptococcal infections are followed by ARF.7 ${ }^{70}$

By the 1980s acute rheumatic fever was considered a vanishing disease that had disappeared in the Western world. ${ }^{71,72}$ Some local revivals of acute rheumatic fever were registered in the United States $(\mathrm{N}=164)$ and in Italy $(\mathrm{N}=21)$, but closer analysis suggested that antibiotics did not play an important role. ${ }^{73,74}$ The morbidity and mortality rates for acute rheumatic fever in Western countries had clearly been declining before the use of antibiotics in the 1950s, and an effect of antibiotic use could not be shown. ${ }^{75,76}$ That some guidelines rely on the results of the Fort Warren studies, whereas others do not, may explain the observed differences. Likewise, regional variation of the incidence of acute rheumatic fever could contribute. The guidelines in our survey, however, did not originate from countries where acute rheumatic fever is still endemic (Aboriginal population of northern Australia, some developing countries, and tropical regions).

Where some guidelines recommend penicillin to prevent acute rheumatic fever (FR03, FI04, CA07, US08-10), other guidelines (BE01, NL02, E05, SC06) consider acute sore throat, even a streptococcal infection, as a self-limiting disease and state that antibiotics have only a limited effect on shortening the clinical evolution. ${ }^{42,57,58,75-79}$

Guidelines also differ with regard to the use of diagnostic tests. Those promoting outpatient tests, either a rapid antigen test or a throat culture (FR03, FI04, CA07, US08-10), recommend penicillin to treat GABHS. Others (BE01, NL02, E05, SC06) discourage diagnostic testing, and reserve antibiotics for high-risk patients only.

\section{Important Differences of Evidence}

Two North American (US08, US09) and the Canadian guidelines do not refer to relevant European trials. Both North American guidelines do not cite the Cochrane review (Table 3 ). Other authors have mentioned that only a few guidelines use formal, systematic methods to combine scientific data. ${ }^{13}$ Also, Cochrane reviews are not always used even though they may be among the most relevant sources of evidence. ${ }^{12}$ It was not possible to assess the methods used by guideline developers to select scientific evidence supporting the guidelines.

Perhaps the lack of European trials ${ }^{42,57-58}$ in most North American guidelines is caused by selection bias. A recent study found that open review of abstracts (when authors' names and institutions are included) favors authors from the United States or from English-speaking countries outside the United States and from prestigious academic institutions. ${ }^{80}$ This finding cannot explain why the Cochrane review was not included, however.

We found that evidence is not interpreted in the same way, perhaps because North American guidelines are often developed by (ear, nose, and throat) specialists, whereas the first authors of the Belgian, Dutch, English, and Scottish guidelines are family physicians. Finally, although we have identified fundamental differences between most North American and European guidelines, 2 European guidelines, the French and Finnish, comply 
with the American guidelines. The French guideline does not refer to the Cochrane review, whereas the Finnish guideline mentions it as 1 of its 5 references. As a result, in Europe the different management recommendations are also a topic for further research. ${ }^{81}$

Differences among guidelines are not merely academic; they have important consequences for daily practice. ${ }^{82}$ A patient consulting a family physician for acute sore throat will be managed differently according to the country. In France, North America, or Finland, a diagnostic test will be performed, and the treatment will depend on its result. In England, Scotland, Belgium, or the Netherlands, physicians will not use a diagnostic test, and the decision to prescribe penicillin will depend mainly on the patient's illness severity. Both approaches are based on scientific evidence. The differences seem to be related to selection or interpretation of the available studies. More uniform development methods could lead to more uniform guidelines, and when implemented, to more uniform practice. Our findings support the need for a transparent development procedure as recommended by WHO. The next step would be to convene guideline developers from various countries and learn more about how they weigh the evidence and how they formulate conclusions.

National guidelines on acute sore throat promote different clinical approaches, recommend different treatments, and cite different evidence. There is no evidence that regional variation is appropriate. Introduction of an explicit guideline development method for both European and North American guidelines may lead to more uniformity in the diagnosis and management of acute sore throat.

To read or post commentaries in response to this article, see it online at http://www.annfammed.org/cgi/current/full/5/5/436.

Submitted December 30, 2006; submitted revised March 22, 2007; accepted April 9, 2007.

Key words: Practice guideline [publication type]; acute sore throat; pharyngitis; primary health care; family practice; evidence-based medicine

\section{References}

1. Bero LA, Grilli R, Grimshaw JM, Harvey E, Oxman AD, Thomson MA. Closing the gap between research and practice: an overview of systematic reviews of interventions to promote the implementation of research findings. The Cochrane Effective Practice and Organization of Care Review Group. BMJ. 1998;317(7156):465-468.

2. Sackett DL, Rosenberg WMC, Gray JAM, Haynes RB, Richardson WS. Evidence-based medicine: what it is and what it isn't. BMJ. 1996;312(7023):71-72.

3. Wiley Interscience. The Cochrane Library. http://www.thecochranelibrary.com.

4. National Health and Medical Research Council. A Guide to the Development, Implementation and Evaluation of Clinical Practice Guidelines. Canberra, National Health and Medical Research Council; 1998.
5. Eisinger F, Geller G, Burke W, Holtzman NA. Cultural basis of differences between US and French clinical recommendations for women at increased risk of breast and ovarian cancer. Lancet. 1999;353(9156):919-920.

6. Fahey TP, Peters TJ. What constitutes controlled hypertension? Patient based comparison of hypertension guidelines. BMJ. 1996;313(7049):93-96

7. Burgers JS, Bailey J, Klazinga N, Van der Bij A, Grol R, Feder G. Inside guidelines: comparative analysis of recommendations and evidence in diabetes guidelines from 13 countries. Diabetes Care. 2002;25(11):1933-1939.

8. Vogel N, Burnand B, Vial Y, Ruiz J, Paccaud F, Hohlfeld P. Screening for gestational diabetes: variation in guidelines. Eur J Obstet Gynecol Reprod Biol. 2000;91(1):29-36.

9. Thomson R, McElroy H, Sudlow M. Guidelines on anticoagulant treatment in atrial fibrillation in Great Britain: variation in content and implications for treatment. BMJ. 1998;316(7130):509-513.

10. Beck C, Cody M, Souder E, Zhang M, Small GW. Dementia diagnos tic guidelines: methodologies, results and implementation costs. J Am Geriatr Soc. 2000;48(10):1195-1203.

11. Littlejohns P, Cluzeau F, Bale R, Grimshaw J, Feder G, Moran S. The quality and quantity of clinical practice guidelines for the management of depression in primary care in the UK. Br J Gen Pract. 1999;49(440):205-210.

12. Silagy CA, Stead L, Lancaster T. Use of systematic reviews in clinical practice guidelines: case study of smoking cessation. BMJ. 2001;323(7317):833-836.

13. Shaneyfelt TM, Mayo-Smith MF, Rothwangl J. Are guidelines following guidelines: the methodological quality of clinical practice guidelines in the peer-reviewed medical literature. JAMA. 1999;281(20):1900-1905.

14. Grilli R, Magrini N, Penna A, Mura G, Liberati A. Practice guidelines developed by specialty societies: the need for a critical appraisal. Lancet. 2000;355(9198):103-106.

15. De Maeseneer J, Derese A. European general practice guidelines: a step too far? Eur J Gen Pract. 1999;5(3):86-87.

16. van Driel ML, De Sutter $A$, Deveugele $M$, et al. Are sore throats patients who hope for antibiotics actually asking for pain relief? Ann Fam Med. 2006;4(6):494-499.

17. Butler CC, Rolnick S, Pill R, Maggs-Rapport F, Stott N. Understanding the culture of prescribing: qualitative study of general practitio ners' and patients' perceptions of antibiotics for sore throats. BMJ. 1998;317(7159):637-642.

18. Christiaens T, De Backer D, Burgers J, Baerheim A. Guidelines, evidence, and cultural factors. Comparison of four European guidelines on uncomplicated cystitis. Scand J Prim Health Care. 2004;22(3):141-145.

19. Schünemann HJ, Fretheim A, Oxman A. Improving the use of research evidence in guideline development: 1 . Guidelines for guidelines. Health Res Policy Syst. 2006;4:13.

20. Oxman A, Schünemann $H$, Fretheim A. Improving the use of research evidence in guideline development: 2 . Priority setting. Health Res Policy Syst. 2006;4:14.

21. Fretheim $A$, Schünemann $H$, Oxman $A$. Improving the use of research evidence in guideline development: 3. Group composition and consultation process. Health Res Policy Syst. 2006;4:15.

22. Boyd EA, Bero LA. Improving the use of research evidence in guideline development: 4. Managing conflicts of interests. Health Res Policy Syst. 2006;4:16.

23. Fretheim A, Schünemann $H$, Oxman A. Improving the use of research evidence in guideline development: 5 . Group processes. Health Res Policy Syst. 2006;4:17.

24. Schünemann $H$, Oxman A, Fretheim A. Improving the use of research evidence in guideline development: 6 . Determining which outcomes are important. Health Res Policy Syst. 2006;4:18. 
25. Oxman A, Schünemann $H$, Fretheim A. Improving the use of research evidence in guideline development: 7 . Deciding what evidence to include. Health Res Policy Syst. 2006;4:19.

26. Oxman A, Schünemann $H$, Fretheim A. Improving the use of research evidence in guideline development: 8 . Synthesis and presentation of evidence. Health Res Policy Syst. 2006;4:20.

27. Schünemann H, Fretheim A, Oxman A. Improving the use of research evidence in guideline development: 9 . Grading evidence and recommendations. Health Res Policy Syst. 2006:4:21.

28. Schünemann $H$, Fretheim A, Oxman A. Improving the use of research evidence in guideline development: 10 . Integrating values and consumer involvement. Health Res Policy Syst. 2006;4:22.

29. Edejer T. Improving the use of research evidence in guideline development: 11. Incorporating considerations of cost-effectiveness, affordability and resource implications. Health Res Policy Syst. 2006;4:23.

30. Oxman A, Schünemann $H$, Fretheim A. Improving the use of research evidence in guideline development: 12 . Incorporating considerations of equity. Health Res Policy Syst. 2006;4:24.

31. Schünemann $H$, Fretheim A. Oxman. Improving the use of research evidence in guideline development: 13. Applicability, transferability and adaptation. Health Res Policy Syst. 2006;4:25.

32. Oxman AD, Schünemann HJ, Fretheim A. Improving the use of research evidence in guideline development: 14 . Reporting guidelines. Health Res Policy Syst. 2006;4:26

33. Fretheim A, Schünemann H. Oxman. Improving the use of research evidence in guideline development: 15. Disseminating and implementing guidelines. Health Res Policy Syst. 2006;4:27.

34. Oxman A, Schünemann $H$, Fretheim A. Improving the use of research evidence in guideline development: 16. Evaluation. Health Res Policy Syst. 2006;4:28.

35. Cruse H, Winiarek M, Marshburn J, Clark O, Djulbegovic B. Quality and methods of developing practice guidelines. BMC Health Serv Res. 2002;2(1):1

36. Park M. Development and evaluation of online evidence based guide line bank system. Stud Health Technol Inform. 2006;122:105-108.

37. Calderon C, Rotaeche R, Etxebarria A, Marzo M, Rico R, Barandiaran M. Gaining insight into the clinical practice guideline development processes: qualitative study in a workshop to implement the GRADE proposal in Spain. BMC Health Serv Res. 2006;6:138.

38. Moreira T, May C, Mason J, Eccles M. A new method of analysis enabled a better understanding of clinical practice guideline development processes. J Clin Epidemiol. 2006;59:1199-1206.

39. Fervers B, Burgers JS, Haugh MC, et al. Adaptation of clinical guidelines: literature review and proposition for a framework and procedure. Int J Qual Health Care. 2006;3(3):167-176.

40. van Everdingen JJ. Evidence-based guidelines in the organization of medical care [Dutch]. Ned Tijdschr Geneeskd. 2005;149(21):1142-1143.

41. Institute of Medicine. Field MS, Lohr KN, eds. Clinical Practice Guidelines: Directions for a New Program. Washington DC: National Academy Press; 1990.

42. De Meyere M, Mervielde I, Verschraegen G, Bogaert M. Effect of penicillin on the clinical course of streptococcal pharyngitis in general practice. Eur J Clin Pharmacol. 1992;43(6):581-585.

43. De Meyere M, Matthys J, Cox T. Guideline acute sore throat [Dutch and French]. Brussels: Belgian Antibiotic Policy Coordination Committee, 2001. http://www.health.fgov.be/antibiotics

44. De Meyere M, Matthys J. Guideline acute sore throat [Dutch] Huisarts Nu. 1999;28:193-201.

45. Dagnelie CF, Zwart S, Balder FA, Romeijnders ACM, Geijer RMM NHG-standaard Acute Keelpijn (eerste herziening). Huisarts Wet. 1999:42: 271-278. (Guideline on acute tonsillitis of the Dutch College of General Practitioners, first revision.).
46. Agence Francaise de Securite Sanitaire des Produits de Sante. Systemic antibiotic treatment in upper and lower respiratory tract infections: official French guidelines. Clin Microbiol Infect. 2003;9:1162-1178.

47. Duodecim. Sore throat and tonsillitis. National Guideline Clearinghouse. 2001. http://www.guideline.gov.

48. National Health Service. Acute sore throat. http://www.prodigy. nhs.uk.

49. Scottish Intercollegiate Guidelines Network. Management of sore throat. http://www.sign.ac.uk.

50. British Columbia Ministry of Science Web site. Diagnosis and management of sore throat. http://www.hlth.gov.bc.ca

51. National Guideline Clearinghouse. Acute pharyngitis. http://www. guideline.gov

52. Bisno AL, Gerber MA, Gwaltney JM, et al. Practice guidelines for the diagnosis and management of group A streptococcal pharyngitis. Clin Infect Dis. 2002;35(2):113-25.

53. Snow V, Mottur-Pilson C, Cooper RJ, Hoffman JR; American Academy of Family Physicians; American College of Physicians-American Society of Internal Medicine; Centers for Disease Control. Principles of appropriate antibiotic use for acute pharyngitis in adults. Ann Intern Med. 2001;134(6):506-508.

54. Centor RM, Witherspoon JM, Dalton HP, Brody CE, Link K. De diagnosis of strep throat in adults in the emergency room. Med Decis Making. 1981;1(3):239-246.

55. Denny FW, Wannamaker LW, Brink WR, et al. Prevention of rheumatic fever. Treatment of the preceding streptococcal infection. JAMA. 1950;143(2):151-153

56. Catanzaro FJ, Stetson (A, Morris AJ. The role of the streptococcus in the pathogenesis of rheumatic fever. Am J Med. 1954;17(6): 749-756.

57. Dagnelie C, Van der Graaf Y, De Melker R, et al. Do patients with sore throat benefit from penicillin? A randomised double blind controlled clinical trial with penicillin $\mathrm{V}$ in general practice. $\mathrm{Br} J \mathrm{Gen}$ Pract. 1996;46(411):589-593.

58. Little $\mathrm{P}$, Williamson I. Open randomised trial of prescribing strategies in managing sore throat. BMJ. 1997;314(7082):722-727.

59. Catanzaro FJ, Rammelkamp CH Jr, Chamovitz R. Prevention of rheumatic fever by treatment of streptococcal infections. II. Factors responsible for failure. $N$ Engl J Med. 1958;259:51-57.

60. Chamovitz R, Catanzaro FJ, Stetson CA, Rammelkamp CH. Prevention of rheumatic fever by treatment of previous streptococcal infections. N Engl J Med. 1954;251(12):466-471.

61. Houser HB, Eckhardt GC, Hahn EO, et al. Effect of aureomycin in treatment of streptocoocal sore throat on the streptococcal carrier state, the immunologic response of the host, and the incidence of acute rheumatic fever. Pediatrics. 1953;12(6):593-606.

62. Wannamaker L, Rammelkamp C Jr, Denny F, et al. Prophylaxis of acute rheumatic fever by treatment of the preceding streptococcal infection with various amounts of depot penicillin. Am J Med. 1951;10(6):673-695.

63. Spink W, Rantz L, Boisvert $P$, Coggshall H. Sulfadiazine and penicillin for haemolytic streptococcus infections of the upper respiratory tract. Arch Intern Med. 1946;77:260-294.

64. Weinstein L, Le Frock J. Does antimicrobial therapy of streptococ cal pharyngitis or pyoderma alter the risk of glomerulonephritis? J Infect Dis. 1971;124(2):229-231.

65. Siegel AC, Johnson EF, Stollerman GH. Controlled studies of streptococcal pharyngitis in a paediatric population. $N$ Engl J Med. $1961 ; 265: 559-571$

66. Saslaw M, Streitfeld M. Group A haemolytic streptococci in relation to rheumatic fever. Am J Dis Child. 1956;91:555-560. 
67. Goslings WR, Valkenburg HA, Bots AW, et al. Attack rates of streptococcal pharyngitis, rheumatic fever and glomerulonephritis in the general population. I. A controlled pilot study of streptococcal pharyngitis in one village. N Engl J Med. 1963;268:687-694.

68. Haverkorn MJ, Valkenburg HA, Goslings WR. Streptococcal pharyngitis in the general population. I. A controlled study of streptococcal pharyngitis and its complications in the Netherlands. J Infect Dis. 1971;124(4):339-347.

69. Valkenburg HA, Haverkorn MJ, Goslings WR, et al. Streptococcal pharyngitis in the general population. II The attack rate of rheumatic fever and acute glomerulonephritis in patients not treated with penicillin. J Infect Dis. 1971;124(4):348-358.

70. Antibiotics and sore throat [Editorial]. Lancet. 1957; 272(6979):1128-1130

71. Gordis L. The virtual disappearance of rheumatic fever in the United States: lessons in the rise and fall of disease. Circulation. 1985;72(6):1155-1162.

72. Land MA, Bisno AL. Acute rheumatic fever: a vanishing disease in suburbia. JAMA. 1983;249(7):895-898.

73. Congeni B, Rizzo C, Congeni J, Streenvasan V. Outbreak of acute rheumatic fever in Northeast Ohio. J Pediatr. 1987;111(2):176-179.

74. Bonora G, Rogari P, Acerbi L, et al. Outbreak of acute rheumatic fever in Northern Italy. J Pediatr. 1989;114(2):334.
75. Howie JG, Foggo BA. Antibiotics, sore throats and rheumatic fever. J R Coll Gen Pract. 1985;35(274):223-224.

76. Glover JA. War-time decline of acute rheumatism. Lancet. 1943; 2:51-52.

77. Del Mar CB, Glasziou PP. Antibiotics for the symptoms and complications of sore throat. In: Douglas R, Bridges-Webb C, Glasziou P, Lozano J, Steinhoff M, Wang E, eds. Acute Respiratory Infections Module of the Cochrane database of Systematic reviews, [updated 03 June 1997]. Available in the Cochrane Library.

78. Pichichero ME, Disney FA, Talpey WB, et al. Adverse and beneficial effects of immediate treatment of group $A$ beta-haemolytic streptococcal pharyngitis with penicillin. Pediatr Infect Dis. 1987;6(7):634-643.

79. Randolph M, Gerber M, Demeo K, Wright L. Effect of antibiotic therapy on the clinical course of streptococcal pharyngitis. J Pediatr. 1985;106(6):870-875.

80. Ross JS, Gross CP, Desai MM, et al. Effect of blinded peer review on abstract acceptance. JAMA. 2006;295(14):1675-1680.

81. De Maeseneer JM, van Driel ML, Green LA, van Weel C. The need for research in primary care. Lancet. 2003;362(9392):1314-1319.

82. Linder JA, Chan JC, Bates DW. Evaluation and treatment of pharyngitis in primary care practice. The difference between guidelines is largely academic. Arch Intern Med. 2006;166(13):1374-1379.

\section{CHANGE-OF-ADDRESS FORM FAMMILY MEDICINE}

Please complete this form and mail to the following address or fax to Annals Circulation at 913-906-6080:

Annals of Family Medicine, Circulation Department, 11400 Tomahawk Creek Pkwy, Leawood, KS 66211-2672

Check if member of sponsoring organization:

$\square$ AAFP $\square$ ABFM $\square$ STFM $\square$ ADFM
$\square$ AFMRD $\square$ NAPCRG $\square$ CFPC

ID number from label on your journal cover

OLD Information (Please print.)

Name

Company (if applicable)

Address (Street plus Apt or Ste)

\begin{tabular}{ll}
\hline City & State \\
\hline Country & Postal Code (9-digit ZIP for US) \\
\hline Telephone & Fax \\
\hline E-Mail &
\end{tabular}

NEW Information (Please print.)

\begin{tabular}{ll}
\hline Name \\
\hline Company (if applicable) \\
\hline Address (Street plus Apt or Ste) & \\
\hline City & Postal Code (9-digit ZIP for US) \\
\hline Country & Fax \\
\hline Telephone & \\
\hline E-Mail
\end{tabular}

